Article original

Animal production

\title{
Food and diet relationships of Parachanna obscura (Gunther) and Clarias gariepinus (Burchell) in a newly impounded Osinmo reservoir, Ejigbo, Nigeria
}

\author{
Olusola OLANIYI KOMOLAFE \& Gabriel Augustine OMOSOLA ARAWOMO \\ Department of Zoology, Obafemi Awolowo University, lle-Ife, Nigeria. \\ E-mail: komolafe@oauife.edu.ng
}

\begin{abstract}
The food and diet of two economically important freshwater fish species, Parachanna obscura and Clarias gariepinus were examined in Osinmo reservoir. Gill-net, cast-net and traps were the fishing gears used to collect fish specimens. Morphometric parameters of each fish were taken. Stomach fullness was noted and each stomach preserved in $4 \%$ formalin. Frequency of occurrence and Numerical methods was used to analyse the stomach contents of each fish. The study observed by frequency of occurrence that insects, fish, and algae, constituted $73 \%$ of the stomach contents of $P$. obscura throughout the sampling period. Similarly the stomach contents of $C$. gariepinus were dominated to the tune of $79 \%$ by detritus, mud, fish, algae, insects and diatoms. Slight variation in food items was observed during the dry and rainy seasons. The percentage of non- empty stomachs in dry and rainy seasons increased from $80 \%$ to $89 \%$ in $P$. obscura and from $74.6 \%$ to $83.4 \%$ in C. gariepinus. The two species of fish fed on many related food items and Schoener overlap index values of 0.05 and 0.02 indicated no diet overlap and competition in dry and rainy seasons.
\end{abstract}

Key words: Food items, diet relationship, competition, Parachana obscura, Clarias gariepinus.

\section{INTRODUCTION}

Osinmo reservoir is located in Ejigbo Local Government Area of Osun State of Nigeria. The reservoir was created late 2005 by the impoundment of Osinmo River with a catchments area of about $102 \mathrm{~km}^{2}$. It is from longitude $04^{\circ}$ $21.2^{\prime} \mathrm{E}$ to $04^{\circ} 21.7^{\prime} \mathrm{E}$ and latitude $007^{\circ} 52.8^{\prime} \mathrm{N}$ to $007^{\circ} 53.2^{\prime} \mathrm{N}$. This area occupied a fairly undulating terrain with highest altitude of $365.76 \mathrm{~m}$ above sea level. The vegetation of the area is a low land rainforest with some area of derived grassland [1]. There is heavy rainfall between July and September of each year with an annual rainfall of $130.88 \mathrm{~mm}$ [2]. The substratum of the reservoir is mainly mud and sand with submerged scattered logs of wood. The surface area of the reservoir is about $0.78 \mathrm{sq} . \mathrm{km}$. The highest depth recorded was $6.3 \mathrm{~m}$ during annual flood while the mean was $3.2 \mathrm{~m}$.

Osinmo reservoir was built primarily to supply potable water to the inhabitants of Ejigbo and adjoining villages. The resulting reservoir has however provided a number of ancillary benefits among which is the production of fish to its communities. The food and feeding habits of freshwater fishes had received much attention over the years because the stomach content of fishes may not accurately reflect the consumers' food. This is because some food items might have digested rapidly, thereby leaving little or no recognizable remains [3]. However, stomach content data such as stomach fullness and the percentage of empty stomach are the most direct evidences of evaluating feeding periodicity. Inland fish species had been reported to have access to a vast store of food of all kinds when rivers overflow their banks in rainy seasons [4]. It had also been reported by [5] that the variety of food eaten by fishes varied within species thereby indicating food selectivity.

The food and feeding habits of predatory fish species had been reported. Such species like Hepsetus odoe (African pike), Lates niloticus (Nile perch), Hydrocynus forskalii (tiger fish), Parachanna obscura (snake head) and Clarias gariepinus (cat fish) were found to be piscivorous in their habitats. [6], [7] and [8] observed these species as obligate piscivores that fed on cichlids. Although there are literatures on food and feeding habits of fish in inland water bodies, there is still paucity of information on the dietary requirements of $P$. obscura and $C$. gariepinus most especially in a newly impounded reservoir where the species are yet to be fully established. This study aims at providing information on the abundance of natural food items and competition among the species in the habitat. 


\section{MATERIALS AND METHODS}

Fish specimens for this study were collected between April 2007 and June 2008. Fishing techniques used were gill-netting, cast-netting and traps. The gill-net used was 100 metres long with stretched mesh size of $2.5 \mathrm{~cm}$, and a depth of 4 metres. Gill-net was set overnight at different sites and removed the following morning around 7.00 a.m. A cast-net of $2.5 \mathrm{~cm}$ mesh size was used to catch fish species at different sites in the reservoir. Traps made of Eremospatha with entrances in form of funnels or non-return valves were baited with ripe palm fruits and set in open water and under vegetation cover along the shoreline. The traps were checked every morning for fish. Fish specimens caught with cast net and traps were immediately put in ice-chest and covered with ice to stop further digestion and regurgitation of food materials in the gut. In the laboratory standard morphometric parameters of each fish were recorded. Fish specimens were slit open from the anus to the pectoral fin and the stomach carefully removed. Each stomach was preserved in $4 \%$ formalin. Fish samples were identified using keys prepared by [9] and [10].

Each stomach was slit open and its content carefully removed into a Petri-dish for observation using a compound microscope. Food identification was done to genus and species level where possible with reference to [11]. There are several indices for expressing the quantitative importance of different food items in the diet of fish as reported by [12] and [13]. The present study used the following indices: Gut Repletion Index i.e. the number of non-empty stomach divided by the number of stomachs examined multiplied by 100 . The Frequency of occurrence method gave the number of stomach with each food item and this was expressed as a percentage of all non-empty stomachs. The Numerical method also showed the number of food items of a given type found in all specimens examined and this was expressed as a percentage of all food items [12]. Some food items at varying stages of digestion cannot be identified at the species level. Diet similarity among fish species was investigated using Schoener Overlap Index [14] (C);

$$
C_{x y}=1-0.5 \sum\left|p_{x i}-p_{y i}\right|
$$

Where; $p_{x i}$ and $p_{y i}$ are the proportions by number of prey type $i$ in the diet of fishes $x$ and $y$ in the seasons respectively. Values of $C$ ranges from 0 (no-overlap) to 1 (complete overlap). When there is dietary overlap, index values 0.8 are considered to be indicative of major differences [15].

\section{RESULTS}

Eight families of fish comprising fourteen species were observed in Osinmo reservoir. The Cichlidae accounted for about $59.06 \%$ of all fish caught while Clariidae, Channidae and Hepsetidae families with a percentage of $20.57 \%, 12.63 \%$ and $6.19 .0 \%$ followed respectively. Other families of fish with $1.6 \%$ completed the population (Table 1). The total length, standard length and weight of the smallest $P$. obscura caught were $25.0 \mathrm{~cm}, 21.0 \mathrm{~cm}$ and $148 \mathrm{~g}$. The biggest fish caught measured 39.9 $\mathrm{cm}, 35.4 \mathrm{~cm}$ and $640 \mathrm{~g}$ in total length, standard length and weight respectively (Table, 1). The food items of $P$. obscura showed a variety of algae, zooplankton, and nematode worms while the species fed mostly on fish and insects (Table 2). The monthly percentage of non-empty stomach in P. obscura is as recorded in Table 3. The smallest $C$. gariepinus caught measured 23.1 $\mathrm{cm}$ total length $20.6 \mathrm{~cm}$ standard length and $91 \mathrm{~g}$. The total length, standard length and weight of the biggest fish were $34.4 \mathrm{~cm}, 30.5 \mathrm{~cm}$ and $344 \mathrm{~g}$ respectively (Table, 1). As shown in Table 2, fish remains, detritus and insect dominated the stomach contents of this species. Other food items of importance found in the stomach include algae, rotifers, crustaceans, diatoms and nematode worms. The percentage of non-empty stomach recorded for the species as shown in Table 3.

The food of $P$. obscura showed variation in the dry and rainy seasons. As shown in Tables 2 and 3 high proportion of algae, insects and fish remains were fed upon during the rainy season (April to September), while protozoa and nematode worms also complemented the diet during this period. During the dry season of (October to March), insects and rotifers were the major food items of P.obscura.

C. gariepinus, had a slight variation in its food items in relation to the seasons. The dry season (October to March) showed predominant food items like detritus, mud, diatoms and rotifers in high proportion, while insects, fish, protozoa and algae are in low proportion. At the onset of rainy season (April to September) food items of importance in C. gariepinus included high proportions of insects, fish, algae, crustaceans, and nematode worms (Tables 2 and 3 ). 
In Osinmo reservoir, $P$. obscura fed on algae, rotifers, protozoa, nematode, insects and fish remains. These six food items along with diatoms, mud and detritus were recorded for $C$. gariepinus. By the percentage of frequency of occurrence as shown in Table 2, about $30 \%$ of the diet of $P$. obscura was algae followed by fish and insects with $24 \%$ and $20 \%$ respectively. Rotifers, nematode worms and protozoa were $11 \%, 9 \%$ and $2 \%$ each of the diet. Similarly about $22 \%$ of $C$. gariepinus diet constituted detritus and mud. Very close to it was fish remains $21 \%$, algae $16 \%$ and insects with $14 \%$ respectively. Diatoms, rotifers and crustaceans were $10 \%, 6 \%$ and $5 \%$ each while the least was nematode worms with $3 \%$.
The diet of the two fish species included both green and blue-green algae which were unicellular or filamentous. In P. obscura, Euglena sp. and Cosmarium sp. were very prominent in its diet while Euglena sp. and Microcystis sp. were the major algae in the diet of $C$. gariepinus. The three main diets of $P$. obscura that constituted $73 \%$ of all food intake included fish, algae and insects. In C. gariepinus, five main food items constituting $79 \%$ of all food taken were fish, detritus, algae, insect and diatoms. Table 3 showed monthly variations in stomach fullness, and the percentage of non-empty stomachs in $P$. obscura and $C$. gariepinus.

Table 1: Relative abundance and the length-weight range of fish species

\begin{tabular}{|c|c|c|c|c|c|}
\hline \multirow[b]{2}{*}{ Family/Species } & \multirow[b]{2}{*}{$\begin{array}{l}\text { Number of } \\
\text { fish }\end{array}$} & \multirow[b]{2}{*}{$\begin{array}{l}\% \text { of } \\
\text { fish }\end{array}$} & \multicolumn{3}{|c|}{ Range } \\
\hline & & & $\begin{array}{l}\text { Total Length } \\
\text { (cm) }\end{array}$ & $\begin{array}{c}\text { Standard } \\
\text { Length }(\mathrm{cm})\end{array}$ & $\begin{array}{l}\text { Weight } \\
\text { (g) }\end{array}$ \\
\hline Osteoglossidae & 2 & 0.07 & & & \\
\hline Heterotis niloticus Cuvier & 2 & 0.07 & $25-39.9$ & $21-35.5$ & $148-640$ \\
\hline Mormyridae & 30 & 1.06 & & & \\
\hline $\begin{array}{l}\text { Gnathonemus cyprinoides } \\
\text { Linnaeus }\end{array}$ & 9 & 0.32 & $8.8-27.1$ & $7.4-23.2$ & $6.0-176$ \\
\hline $\begin{array}{l}\text { Gnathonemus senegalensis } \\
\text { Steindchner }\end{array}$ & 10 & 0.35 & $17.1-24.1$ & $14.1-20.5$ & $48-150$ \\
\hline $\begin{array}{l}\text { Mormyrus rume Cuvier \& } \\
\text { Valenciennes }\end{array}$ & 11 & 0.39 & $13.9-40.6$ & $12.4-35.0$ & $17-445$ \\
\hline Cyprinidae & 3 & 0.1 & & & \\
\hline Barbus callipterus Boulenger & 3 & 0.1 & $7.8-8.1$ & $6.0-6.5$ & $2.0-2.7$ \\
\hline Hepsetidae & 174 & 6.19 & & & \\
\hline Hepsetus odoe Bloch & 174 & 6.19 & $12.7-44.0$ & $10.2-36.0$ & $12-678$ \\
\hline Malapteruridae & 8 & 0.28 & & & \\
\hline Malapterurus electricus Gmelin & 8 & 0.28 & $20.2-22.1$ & $16.7-18.2$ & $106-136$ \\
\hline Clariidae & 578 & 20.57 & & & \\
\hline Clarias gariepinus Burchell & 578 & 20.57 & 23.1-34.4 & $20.6-30.5$ & $91-344$ \\
\hline Channidae & 355 & 12.63 & & & \\
\hline Parachanna obscura Gunther & 355 & 12.63 & $25.0-39.9$ & $21.0-35.4$ & $148-640$ \\
\hline Cichlidae & 1659 & 59.06 & & & \\
\hline Hemichromis fasciatus Peter & 236 & 8.4 & $10.5-14.8$ & $8.4-11.5$ & $21.7-64$ \\
\hline Oreochromis niloticus Trewavas & 14 & 0.5 & $13.2-45.2$ & $10.2-36.0$ & $38-1720$ \\
\hline $\begin{array}{l}\text { Pelmatochromis taeniatus } \\
\text { Sauvage }\end{array}$ & 153 & 5.45 & $9.5-16.5$ & $7.5-12.8$ & $11-80$ \\
\hline Sarotherodon galilaeus Trewavas & 462 & 16.45 & $9.5-32.5$ & $7.1-26.1$ & $18.6-632$ \\
\hline Tilapia zillii Gervais & 794 & 28.3 & $8.1-31.7$ & $6.3-22.7$ & $10-508$ \\
\hline
\end{tabular}


Table 2: Summary of food items in the stomachs of $P$. obscura, $C$. gariepinus and diet seasonal variation

\begin{tabular}{|c|c|c|c|c|c|c|c|c|c|c|c|c|}
\hline \multirow[b]{3}{*}{ Food items } & \multicolumn{4}{|c|}{ Frequency of occurrence } & \multicolumn{4}{|c|}{ Numerical method } & \multicolumn{4}{|c|}{ Diet seasonal variation } \\
\hline & \multicolumn{2}{|c|}{ Number } & \multicolumn{2}{|c|}{$\%$} & \multicolumn{2}{|c|}{ Number } & \multicolumn{2}{|c|}{$\%$} & \multicolumn{2}{|c|}{ P. obscura } & \multicolumn{2}{|c|}{ C. gariepinus } \\
\hline & $\begin{array}{l}\text { Ð్రి } \\
\mathbb{8} \\
0 \\
0\end{array}$ & 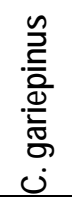 & $\begin{array}{l}\tilde{0} \\
\text { ర్d } \\
8 \\
0 \\
0\end{array}$ & 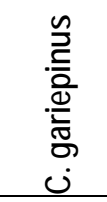 & 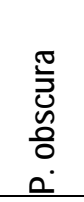 & $\begin{array}{l}\frac{3}{8} \\
\frac{5}{8} \\
\frac{8}{5} \\
0 \\
0\end{array}$ & 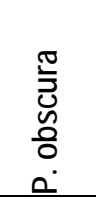 & 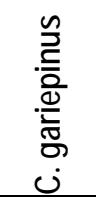 & $\grave{a}$ & $\frac{5}{98}$ & 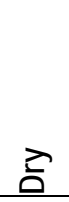 & 要 \\
\hline \multicolumn{13}{|l|}{ Algae } \\
\hline Oscilatoria sp. & 6 & 8 & 1.92 & 1.24 & 21 & 48 & 2.49 & 1.94 & - & + & - & + \\
\hline Microcytis sp. & 11 & 36 & 3.51 & 5.60 & 36 & 436 & 4.28 & 17.64 & - & + & - & + \\
\hline Coelosphaerium sp & 4 & - & 1.28 & - & 18 & - & 2.14 & - & + & - & - & - \\
\hline Spirogyra sp. & - & 4 & - & 0.62 & - & 80 & - & 3.24 & - & - & + & + \\
\hline Closterium sp. & 15 & - & 4.79 & - & 60 & - & 7.13 & - & - & + & - & - \\
\hline Euglena sp. & 27 & 41 & 8.63 & 6.38 & 31 & 590 & 3.68 & 23.87 & - & + & + & + \\
\hline Cosmarium sp. & 18 & - & 5.75 & - & 42 & - & 4.99 & - & - & + & - & - \\
\hline Trachelomonas sp. & - & 11 & - & 1.71 & - & 10 & - & 0.40 & - & - & - & + \\
\hline Pediastrum sp. & 10 & - & 3.19 & - & 51 & - & 6.06 & - & + & - & - & - \\
\hline \multicolumn{13}{|l|}{ Protozoans } \\
\hline Amoeba sp. & 2 & - & 0.64 & - & 5 & - & 0.59 & - & + & + & - & - \\
\hline Paramecium sp. & 3 & 14 & 0.96 & 2.18 & 8 & 59 & 0.95 & 2.39 & + & + & + & + \\
\hline \multicolumn{13}{|l|}{ Crustaceans } \\
\hline Daphnia sp. & - & 16 & - & 2.49 & - & 37 & - & 1.50 & - & - & - & + \\
\hline Cladocerans sp. & - & 13 & - & 2.02 & - & 70 & - & 2.83 & - & - & - & + \\
\hline \multicolumn{13}{|l|}{ Diatoms } \\
\hline Navicula sp. & - & 15 & - & 2.33 & - & 88 & - & 3.56 & - & - & + & - \\
\hline Diatoma sp. & - & 27 & - & 4.20 & - & 61 & - & 2.47 & - & - & - & + \\
\hline Synedra sp. & - & 18 & - & 2.80 & - & 43 & - & 1.74 & - & - & - & + \\
\hline Flagilaria sp. & - & 7 & - & 1.09 & - & 54 & - & 2.18 & - & - & - & + \\
\hline \multicolumn{13}{|l|}{ Rotifers } \\
\hline Filinia sp. & 21 & - & 6.71 & - & 72 & - & 8.55 & - & - & - & - & - \\
\hline Rotaria sp. & - & 15 & - & 2.33 & - & 66 & - & 2.67 & - & - & + & - \\
\hline Branchionus sp. & 14 & - & 4.47 & - & 67 & - & 7.96 & - & - & - & + & - \\
\hline Lecane sp. & - & 22 & - & 3.42 & - & 48 & - & 1.94 & - & - & - & - \\
\hline \multicolumn{13}{|l|}{ Nematodes } \\
\hline Nematode worms & 29 & 21 & 9.27 & 3.27 & 81 & 61 & 9.62 & 2.47 & + & - & - & + \\
\hline \multicolumn{13}{|l|}{ Vertebrates } \\
\hline Fish remains & 74 & 137 & 23.64 & 21.31 & 204 & 251 & 24.23 & 10.15 & + & + & + & + \\
\hline \multicolumn{13}{|l|}{ Insects } \\
\hline Insect remains & 63 & 91 & 20.13 & 14.15 & 12.3 & 438 & 14.60 & 17.72 & + & + & + & + \\
\hline Mud & - & 25 & - & 3.89 & - & - & - & - & - & - & + & + \\
\hline Detritus & - & 113 & - & 17.57 & - & - & - & - & - & - & + & + \\
\hline $\begin{array}{l}\text { Unidentified food } \\
\text { items }\end{array}$ & 16 & 9 & 5.11 & 1.40 & 23 & 32 & 2.73 & 1.29 & + & + & + & + \\
\hline
\end{tabular}


Table 3: Monthly analysis of non-empty stomach in P. obscura and C. gariepinus

\begin{tabular}{lcccccc}
\hline \multirow{2}{*}{ Month } & \multicolumn{2}{c}{$\begin{array}{c}\text { Number of stomach } \\
\text { examined }\end{array}$} & \multicolumn{2}{c}{ No of empty stomach } & \multicolumn{2}{c}{ \% of non-empty stomach } \\
\cline { 2 - 7 } & P. obscura & C. gariepinus & P. obscura & C. gariepinus & P. obscura & C. gariepinus \\
\hline April 2006 & 15 & 28 & 2 & 4 & 86.7 & 85.7 \\
May " & 18 & 45 & 1 & 11 & 94.4 & 75.6 \\
June " & 16 & 40 & 1 & 7 & 93.7 & 82.5 \\
July " & 32 & 20 & 3 & 2 & 90.6 & 90.0 \\
August " & 40 & 50 & 7 & 13 & 82.5 & 74.0 \\
September " & 28 & 47 & 2 & 9 & 92.9 & 80.8 \\
October " & 37 & 29 & 2 & 8 & 94.6 & 72.4 \\
November " & 20 & 41 & 1 & 15 & 95.0 & 63.4 \\
December " & 18 & 38 & 4 & 7 & 77.8 & 81.6 \\
January 2007 & 21 & 25 & 3 & 6 & 85.7 & 76.0 \\
February " & 36 & 50 & 8 & 13 & 77.8 & 74.0 \\
March & 19 & 53 & 7 & 11 & 63.2 & 79.2 \\
\hline
\end{tabular}

\section{DISCUSSION AND CONCLUSION}

The main food items of $P$. obscura and $C$. gariepinus in Osinmo reservoir were fish, insect, algae and rotifers while detritus and mud which constituted one of the main food items for $C$. gariepinus were not included in the $\operatorname{diet}$ of $P$. obscura. This feeding pattern was also recorded by [8] in upper Ogun River and [16] in Opa reservoir. Other food items include protozoa, diatoms, crustaceans and nematode worms. The presence of detritus and mud in the stomach of $C$. gariepinus suggested that the species was a bottom grazer with high proportion of diatoms in its diet as reported by [16] and [17]. P. obscura as shown by its food items was an obligate piscivore [8]. The two species of fish basically fed on many related food items such as fish, algae, insects, rotifers, protozoa and nematodes. The value of Schoener Index of proportional overlap [14] for the two species was 0.02 indicating no feeding overlap.

Similarity in ecological niche of the species show slight differences in the selection of complementary food items. Habitat preference of $P$. obscura was marginal vegetation and flood plain [18] while inshore and flooded banks with allochthonous organic matters was preferred by $C$. gariepinus [16]. $P$. obscura fed mostly on insects and fish in dry season while abundant fish, nematodes and algae were consumed in the rainy season. Detritus, mud diatoms and algae were the food items of $C$. gariepinus in dry season while algae, fish, insects and nematode comprised the main food in rainy season. Food items of each fish in dry and rainy seasons slightly differ and
Schoener Overlap Index values for the two species in the seasons were 0.05 and 0.02 respectively. The food items of $P$. obscura and $C$. gariepinus did not overlap in the habitat.

Monthly variations in feeding habits did not affect the stomach fullness of $P$. obscura and $C$. gariepinus in the reservoir. The percentage of non-empty stomachs showed no reduction of food items although slight increase in food composition occurred. There was variation in the proportion of non-empty stomachs recorded in the dry and rainy seasons for the two species. Presently, an average of $83.4 \%$ and $89.3 \%$ non-empty stomachs were recorded for $P$. obscura in dry and rainy seasons while $74.6 \%$ and $80 \%$ non-empty stomachs were recorded for $C$. gariepinus. Most stomachs had food and some with remnants of digested food materials. The number of nonempty stomachs recorded might be due to food regurgitation or complete digestion due to struggling by fish to escape in the gill-nets or traps. Cast-net specimens were mostly with food items which gave it an edge over other fishing gears. The rainy season also witnessed high volume of water in the reservoir from the catchments area and additional food items recorded for the species included protozoa and nematode worms.

The diatoms recorded for $C$. gariepinus in the dry season was not found in the diet during the rainy season. However, additional food items for the species included high proportions of crustaceans and nematode worms. As shown in Table 2, $P$. obscura, had $89.3 \%$ non-empty stomach in ${ }^{\text {th- }}$ rainy season between April and Septem 
compared to $83.4 \%$ non-empty stomach in the dry season October to March. The percentage of nonempty stomach for C. gariepinus in rainy season (April to September) was $80.00 \%$ as compared to $74.6 \%$ non-empty stomach in the dry season (October to March). The relatively low levels of non-empty stomach percentages observed in the rainy season for the species was as a result of increase in the variety of food items available for $P$. obscura and $C$. gariepinus in view of the allochtonous materials brought into the reservoir by flood in the raining season.

The food and feeding habits of $C$. gariepinus in the present study was also observed for 0 . niloticus and C. gariepinus in Opa reservoir [19]; [20]. The variety of food items of $P$. obscura in the present study was higher in number compared to the observation of [18] and [16] who reported plant materials and detritus for the species. Also the nineteen food items found in the stomachs of $C$. gariepinus were higher than thirteen food items recorded for the species in Opa reservoir by [16]. There was no competition between $P$. obscura and $C$. gariepinus in the reservoir. Abundance of food materials brought into the newly constructed reservoir was fed upon by the fishes throughout the year. The diet of the fish species did not overlap and being omnivores can thus co-exist in the habitat.

\section{ACKNOWLEDGEMENTS}

The Fisheries Department of Osun State Ministry of Agriculture is appreciated for securing the assistance of Mr Adeolu in collecting fish samples.

\section{REFERENCES}

1. Keay, R.W.J. 1959. An outline of Nigerian Vegetation. Federal Government Printer. Lagos. 46p.

2. Komolafe, O.O. and Arawomo, G.A.O. 2008. Preliminary observations on fish species in a newly impounded Osinmo reservoir. Turkish Journal of Fisheries and Aquatic sciences. 8: 289-292.

3. Bagenal, J.B. 1978. Methods for assessment of fish production in freshwaters. Blackwell Scientific Publications. Oxford. 365p.

4. Bowman, R.E. and Bowman, E.W. 1980. Diurnal variation in the feeding intensity and catchability of Silver Hake (Merluccius hilinearis) Can. J. Fish. Aquat. Sc., 37: j65-1572.
5. Pearcy, W.G. and Jullie, W.A. 1974. Food habits of deep sea macrourid fishes off the Oregon Coast. Deep. Sea Res. Oceanorg. Abstr., 21(a): 745-759.

6. Holden, M.J. 1970. The feeding habits of Alestes baremose and Hydrocynus forskahlii (Pisces) in Lake Albert, East Africa. J. Zool., London. 161: 137-144.

7. Arawomo G.A.O. 1987. The fish fauna of the rivers in the new Federal capital territory, Abuja, Nigeria, Ife Journal of Science, 2 (1): 37-43.

8. Adebisi, A.A. 1981. Analysis of the stomach contents of the piscivores fishes of the upper Ogun River in Nigeria. Hydrobiologia, 79: 167-177.

9. Reed, W.; Burchardm J.; Hopson, A.J.; Jenness, J. amd Ibrahim, Y. 1967. Fish and Fisheries of Northern Nigeria. Published by Ministry of Agriculture, Northern Nigeria. 224p.

10. Adesulu, E.A. and Sydenham, D.H.J. 2007 The freshwater fishes and fisheries of Nigeria. Macmillan Nigeria Publishers Ltd. Lagos, Ibadan. 397p.

11. Edmondson, W.T. 1959. Freshwater Biology. $2^{\text {nd }}$ Edn., John Wiley and Sons Inc. $1248 p$.

12. Costal, J. L., Almeida, P. R., Moreira, F. M. and Costal, M. J. 1992. On the food of the European eel Anguilla Anguilla (L): in the upper zone of the Tages estuary, Portugal. J. Fish. Biol., 41: 841-850.

13. Hyslop, E.J. 1986. The growth and feeding habits of Clarias anguillaris during their first season in the flood pools of the SokotoRima River Basin, Nigeria. J. Fish. Biol., 30: 183-192.

14. Schoener, T.W. 1970. Non-synchronous spatial overlap of lizards in patchy habitats. Ecology., 5: 408-418.

15. Cartes, J.R. and Sarda, F. 1989. Feeding ecology of the deep-water aristeid crustacean Ariseus antennatus. Mar. Ecol. Prog., Ser. 54: 229-238.

16. Abayomi, O.S., Arawomo, G.A.O. and Komolafe, 0.0. 2005. Distribution, food and feeding habits of a cat fish, Clarias gariepinus (Burchell, 1822) in Opa reservoir, lle-Ife, Nigeria. Science Focus, 10(1): 62-67.

17. Ayinla, O.A. 1988. The food and feeding habits of African mud catfish, Clarias gariepinus (Burchell, 1822) caught from the 
wild. N.I.O.M.R. Technical paper No. 34 ISBN - 978-2345-031. 13p.

18. Walter, R.C. Jr. and Williams, J.D. 2004. US Geological Survey Circular, 1251.

19. Abayomi, O.S., Arawomo, G.A.O. and Komolafe, O.0. 2005. Distribution, food and feeding habits of a cat fish, Clarias gariepinus (Burchell, 1822) in Opa reservoir, lle-Ife, Nigeria. Science Focus, 10(1): 62-67.
20. Komolafe, O.O. and Arawomo, G.A.O. 2003. The distribution and feeding habits of a cichlid fish, Oreochromis niloticus (Linnaeus) in Opa reservoir lle-lfe, Nigeria. Bioscience Research Communications. 15(5): 379-386. 